\title{
the headless bride
}

\section{Catherine Kidd}

\begin{abstract}
"La mariée sans tête" de Catherine Kidd raconte l'histoire de l'attachement passionné d'une petite fille avec une tête de poupée qu'elle nomme "la tête." La narratrice lutte contre et s'abandonne à son envie pour l'incroyable liberté de la tête. "J'enviais la tête pour ne pas avoir, pour ne pas ÊTRE, un corps." Cet état de ne pas être un corps se frappe à l'aveu de la narratrice qu'elle était trop corporelle. Pour la narratrice, la tête vit l'impossibilité suprême: une vie libre de matérialité. La tête existe en tant que possibilité ultime, "ceà quoi une petite fille peut aspirer, dans son détachement, dans sa rupture avec des pieds maladroits et autres appendices."
\end{abstract}

My first object of desire was a severed head. I was seven or eight if memory serves, which it often doesn't. More often it's me playing chambermaid to my own recollection, rearranging objects on its vanity table to look as unchanging as possible, polishing away the tarnish and rearranging mental furniture to suit its fancy. But I do remember desiring the head, after my father's perennial I'd like to see you get ahead, you need one, which limping pun was not even original, as I found out, seeing it printed on a dozen T-shirts in the window of a Water Street souvenir shop. The T-shirts make a fitting souvenir of my father, who in memory is refigured as a sort of spatial concept or emblem, bearing little physical resemblance to the man but easily transferable onto other things and other people, like an iron-on decal, or a phony tattoo.

But I did get a head, the Christmas when I was seven or eight. It sparkled from beneath the low-hanging boughs of the tree, a kitchenappliance-sized box, wrapped in zig-zag pink \& silver paper, tied with a frothy lepidopterous bow. The bow had made similar appearances in previous years, like a lacy fading ghost of Christmas past, moldering to naphthalene. But under the burlesque light of the tree it remained lovely, and its whispered proposition was ever the same: open me first.

In reality the bow was not tied to the box at all, but stapled to itself in multiple loops and stuck with a dab of adhesive. I had been disillusioned 
to learn this. I had thought my mother was able to tie such elaborate bows herself. She was resourceful, and believed strongly in the importance of presenting agreeable packages. She also believed in occasionally reminding us that her resources were pinched, like the nerve in her back was pinched, and that this pained her.

And so I unwrapped the box carefully, knowing the bow would be preserved to reappear on some other object of desire, some other time. I slipped my father's pen-knife beneath the bands of tape and sliced through until the paper fell away, then clamped my hands like forceps over the temples of the lovely head to lift it carefully out of the box. A small plastic bag of pink hair-ornaments and play-cosmetics fell from the box as well, like those bags of internal organs found in turkeys. For a few moments I could only sit staring at the severed head, until my mother said Well, if I didn't like my new head I could always exchange it for something else. A decent pair of slippers. A manicure set.

What do you say, Alley? prompted my father. Then was I all praise and thank-you's, murmuring that the head was more perfect than I'd ever imagined, the most lovely head I'd ever seen, the most perfect of presents.

And in reality the head wasn't severed at all, severance being predicated on some original attachment to a body, which this head had never known. It was blond, female, single. Its only attachment was a pony-tail of artificial hair which could be fastened in place with a pink plastic barrette and as easily removed. Unlike my own head, the head was pliable and weighed almost nothing. A thumb pressed into its forehead left a dent, which gradually re-inflated when the pressure was removed. It smiled with sealed lips, as I was encouraged to do, as not to expose my crooked teeth.

The head stood about a foot tall and had long shining locks of celestial platinum, while my hair was dark as dirt. Its eyes were the two-dimensional blue of postcard sky, while mine sank back to oily brown, then black, then deeper to infinity, or less profound than that. My eyes were the colour of drugstore sunglasses, that cheap dark glass which tricks the pupil into wide dilation as though it were protected, the retinas only getting more burned for their beguiled openness. I've heard that cheap sunglasses are more damaging than no sunglasses at all. That I'd be better off staring directly into the sun for one ecstatic moment, than walking around behind lenses which only seem to screen the eyes from tiny ultra-violet violences. 
At seven or eight, my eyes sucked in radiance like a vacuum. The world burned silhouettes on my retinas which corresponded in negative to the shapes of objects on the landscape. By the time I was nine I had collected an entire shadow-pantheon of objects, constructed frames around them in my mind. I saw their forms represented everywhere, as though every woman's face were trimmed to fit the portrait-silhouette in the back room of my brain, or every man were Alfred Hitchcock lumbering into the inksketch caricature of himself and sublimating there. I projected these shapes from my eye-beams like a magic lantern, and saw their ghostly forms reflected in everything.

The severed head was like this. She exactly filled the ideal silhouette in my mind of what a little girl might aspire to, in her detachment, in her severance from butterflies in the stomach and clumsy feet and other appendages which couldn't be trusted to function with any grace. If desire was a glass slipper, then the head was that lovely dainty foot which slid into it smoothly and fit perfectly.

She was supported upon a pink plastic pedestal embossed with curly designs. In place of shoulders, the pedestal looped out in two epauletcompartments which held the hair-ornaments and play-cosmetics. The face of the head floated luminous like a spider egg-case, pale and gossamer, self-contained. I thought of spiders because of her hair, which was almost white and slightly sticky, like webs, or hair products. When I flipped the head upside down to peer through her hollow neck and into her cranium, I could see rows of egg-like baubles where the sticky strands of hair were pushed through perforations in the scalp and heat-sealed in place. There was nothing else inside the head at all, except two blue concave bruises which corresponded to her eyes, and a tiny dimple where her nose was - the face of the head in negative relief.

I envied her freedom from attachments. I envied that she never had to shut her eyes to sleep, was always wide-eyed and eager but registered no change of expression whatever. Smug knowingness. Smug ingenuous knowingness, knowing nothing. I envied that she did not have to drag around a body, like other species who spend their lives tethered to their own larval cases, or to communal shell-structures, or to arms and legs. The head's empty-headedness seemed to mean that she had achieved something, in thinking nothing, in conceiving nothing, in seeing-hearing-speaking nothing. I could stick my fingers up the slender tunnel of her neck and hold her aloft in one hand. Like a ballerina, she was easily borne. Were she 
ever to bear progeny, I envisioned these as baby spiders, which would float away immediately after birth to make their own way in the world, independently and elsewhere. Baby spiders arrive with their parachutes ready, know instinctively how to use them, or quickly learn. Then they leave. I envied the head for having, for being, no body. It was her birthright or copyright to remain attached to nothing. And nothing, for its part, would remain attached to her.

After dinner, I carried the head into my room and closed the door. I draped a pale blue chiffon nightie from my mother's dresser over the head's shoulders, over the pink plastic pedestal which stood in place of shoulders, then cupped the back of her graceful nylon scalp in my squarish hand and lead waltzes about the room. I admired how gracefully her blue chiffon no-body flowed in time to music it could hear not at all, admired how she never trod on my toes. I was always treading on people's toes, my mother's toes, though I scarcely ever saw my mother's toes. They were hidden in fluffy blue rabbit-fur slippers, or raised out of harm's way on the foot-rest of her big mustard armchair. This didn't seem to stop me from treading on her toes, she said, but at the same time she also said that I was always getting underfoot. I didn't dare point out the apparent contradiction in this, my dual identity as both treader and trodden upon. I simply understood that as a subject I was an imposition, as an object, an encumbrance. All in all I was too much of a body, and this I had to bear in mind. Mind your tongue, mind your manners, mind your feet you great horsy girl, mind you stay out of harm's way. Enough to make a girl wish for a body which occupied no space at all, so that it could be kept out of harm's way. Enough to make a girl long for a body which occupied negative space.

How delicious then, to be a severed head, transcending all of that. Immortal women were often bodiless. Preserved behind glass inside tiny golden lockets, or framed on gallery walls; embossed on boxes of chocolates and cake mixes, bottles of pancake syrup, backs of coins, packets of cigarettes; preserved on postage stamps, or suspended above the gateways of stone castles. More memorable as heads than they ever were as bodies, and not in anyone's way.

At dinner, my brother made the announcement that both of us had got pinworms. My mother caught him quickly by the elbow and escorted him 
from the table. The grown-ups had been talking of absent persons and suspicions of illness, and other suspicions which couldn't be verified as the persons were absent. My Great Aunt Hilda was listening with some distaste. It was impossible to tell whether she disapproved of the people who were being spoken about, or of the fact they were being spoken about behind their backs. She hadn't seemed to mind about the pinworms, she'd even smiled, a little. Enough that I felt encouraged to mention them again, once my mother returned to her seat, leaving my brother to do his fiveminute time-out in the kitchen.

But it's true, we do have, I said. I've seen them. I was convinced it was some exotic ailment we had, or evidence of genetic malfunction, at least a signal that something was wrong, that something was rotten. There were worms in rotten apples and crawling all inside dead groundhog-bodies at the side of the road. I knew of such things. I assumed that Great Aunt Hilda knew something of them as well, she was very old, she had seen the death of many things. She would know how to tell if a body were dying. She would know better than I did that dead bodies couldn't speak nor do much of anything, and that they were generally disposed of by somebody, being unable to dispose of themselves.

But my mother reached for my arm beneath the table, and pressed a discreet trail of slender half-moons in my flesh with her small pointed nails. Above the table, her mouth was smiling and explaining that at times I tended to forget myself. This was why she was digging her nails into my arm, to remind me of myself. That I was there and that I had arms, which were under the table where no one could see them. I was interested in things which no one could see. Despite turkey \& stuffing, sparkling cranberry-orange relish in its clear crystal bowl, despite candied yams, greenbeans in butter \& cream, turnip mashed with carrots, polished silverware, Aunt Hilda's best bone china, despite the festive paper table-cloth embossed with bells and red bows, all I could think of was whether anyone could see that there was a mangled dead bird on the table.

Mangle. That night I slept on a cot in my Aunt Hilda's kitchen, beside the old washing machine which featured a device called a mangle. The mangle resembled two rolling pins, pressed together like tight white lips, between which wet laundry was fed to wring it out and press it flat. The clothes would emerge pristine and two-dimensional on the other side, as though the machine ate laundry and shat linen sheets and shirts. I'd heard stories of women getting their arms caught in mangles, and tried to imag- 
ine what would get spat out the other side. Long thin arms pressed flat, like the red satin evening gloves my mother complained of never having occasion to wear.

The kitchen smelled of steam and turkey-fat and laundered flannelette. The cot made me think of an ironing board, it creaked like an ironing board when I shifted my weight above then below the metal beam at my tailbone. My mother had pulled it down from a tall cupboard by the cellar door, unfolding its jointed legs until it stood up on all fours. Great Aunt Hilda had contributed a pale green night-light shaped like a little cat-face, winking. She'd plugged it into the wall beside the old washing machine, making the barrel of the machine glow mint-green like an enormous jellied salad, like one of those menacing salads which mixed shredded cabbage with mini-marshmallows as though the two had anything to offer one another.

The night-voices of Great Aunt Hilda's house had not changed in a hundred years. Night spoke in crickets and creaks like the slow turning of a wheel, the groaning of the rafter-beams like oxen, the ticking of the kitchen wall-clock and my own pulse pacing back and forth in attic rooms. Green light washed the contours of the walls and slid over the oval frame of a portrait hung above the cellar door. I was sure the same portrait used to hang upstairs, I'd seen it there. Now sparse green light contorted the head and shoulders of a sallow little girl in a lacy-necked pinafore, her high lunar forehead, low-sloping brow shading the eager little eyes which peered from beneath. Her short curly hair clung close like a plaster cast of itself, and her small tapioca teeth glowed green in the half-light.

Her face was green-tinted as well, like the face of a girl who is sick or envious. I knew she used to hang upstairs because I'd slept in the same room with her once, or I had not slept. There had been a game I couldn't win, against her softly eager eyes defying me to shut mine. Just lie back, there you go. And I would begin to nod off. Then my eyes would open with a start and there she'd be, her veiled eager stare, her odd little smile. I would go down to the ground floor to wake my Great Aunt Hilda, who'd climbed back up the stairs with me to save me from the girl with the tapioca teeth. I had hoped she'd stay until I fell asleep again. My heart sank as I watched her simply reach up and turn the portrait to the wall. I don't think that will help very much, I said. In truth I thought it was much worse, the sallow little face of the girl pressed to the wall like that. She would be furious. She would try to flip the oval frame back over with her tongue, 
and I would have to lie in the dark and listen to the thumping.

Well now Alley don't be silly, my Great Aunt Hilda said. Imagine making such a fuss over a picture. Your grandmother had it painted when your mother was just a little girl like you, you know. Why, it's your own dear mother, after all.

Tonight it was my mother who had the upstairs room, with my brother in a cot at the foot of her bed, while I had been stationed down here in the kitchen with my mother's floating head to watch over me in my sleep. The eyes at the back of her head. I pulled the grey woollen blankets up to my neck, then turned my face away toward the other head, the beautiful blond head in bed beside me, her pale nylon profile green-tinted as well. Over her shoulders I'd draped my pink flannel nightdress, which quite became her, being only a head, she quite became whatever she was dressed in. Her pink flannel no-body lay limp and flat against the cot like a paper doll, or like a fairy tale princess pressed flat between the pages of a book.

Looking down at myself, I appeared the opposite of this. I could not see my own head, but the rest of me was a large grey mass of woollen blankets. If I peered beneath the blankets, I became a naked cluster of pale and rounded shapes like cheeses under glass at a delicatessen. Too much of a body. The milky smell of a body, warm and slightly damp, mingled with the cool artificial scent of the head like those products advertised as unscented which are not. Each of us seemed to have what the other one lacked. But if the head was my first object of desire then perhaps I could be hers, perhaps we could complete each other.

I sat up creaking in the cot and set my bare feet down on the chilled linoleum, with its twisting pattern of cabbages-roses strangling themselves in lovely ways. I nestled my blond severed head in the crook of my arm and let her pink gown flow to the floor like a veil. She smiled sweetly, with sealed lips. I placed her up high like a basket on my head and held her there with one hand, then draped the grey woollen blanket over both of us in such a way that my body was hidden except for my feet. I was able to peek through a crevice in the folds of the blanket to avoid bumping into anything as I shuffled our feet over to the cellar door. Our head looked up.

The portrait would serve well as the Justice, the cellar door above which she was framed resembled one of those lofty wooden podiums where judges preside. In my mind, I fed her her lines one by one like holy wafers, 
while her tiny tapioca teeth grinned green and took them in. Spat them out. It was the first time I'd ever put words in my mother's mouth. We are gathered here in the sight of the winking cat to witness the joining of this head to this body, holy macaroni. If anyone present knows a reason why these two should not be united, let that person speak now or forever rest in pieces.

There was requisite pause. The house creaked, the clock ticked and my pulse paced but no one spoke. I fed the portrait her next lines. Do you, head, take this body to be lawfully yours, to have and to hold things for you, for better or for worse. For richer or for poorer, in sickness and in health, til death does its part or however the words went, they seemed to anticipate the worst. And I was conscious now that the worst parts of the vows referred more to me, the body, than they did to the head, who would never be sick, would never be dead. But I tipped my betrothed head back and forth like one of those glass-ampule birds filled with red fluid which dips its beak into a wine glass, and the head slowly nodded $I$ do.

Beneath the blanket it was dark and becoming very warm, and my arm was beginning to tire from holding up my severed head that way. But cool against the floor were the soles of my feet, pale and green like phosphorescent fish among the tangled vines of cabbage roses. A pale green island with two feet planted on it. This was all I was able to see clearly, everything else was cloaked in thick woollen darkness. My two feet. Our two feet.

Cold feet. I was beginning to have second thoughts. The head had nothing to lose if this union failed, she had never been attached to any body in the first place. She might even begin to miss having no body, having done very well for herself with no body to weigh her down. Blonde, female, single. Bodiless. Bloodless. Unbiodegradable. Immortal women were often figured as bodiless heads, but I had never seen a headless body featured on a postage stamp or a coin or a box of chocolates or preserved in an oval frame, suspended under glass above a cellar door. A body, separated from its head, was anonymous, and mortal. A body by itself was an encumbrance to others, and tended to forget itself. What would I do if I ever lost my head?

Do you, body of Alley, take this head to be yours, for better or for worse, for richer or for poorer, in sickness and in health, for as long as you both shall live? Now the lines came unbidden to my mind, automatically, like the workings of an infernal machine having only one switch to set it into motion and no switch to shut it off. And wouldn't the portrait of my mother have to speak the lines itself, if the head and I were really to be joined? 
A body is mute without its head, but the lips of my beloved head were permanently sealed. I had seen inside her, I had peered down the narrow tunnel of her slender neck and saw she had no tongue. She had no teeth. She had nothing at all inside her skull but the impression of her own face in negative, while the portrait of my mother seemed able to speak words simultaneously with their appearance in my mind, as is the case with putting words in someone's mouth, or taking them from someone's mouth. There is spontaneous correspondence between the synapse of generations. It becomes difficult to tell where words came from, in the beginning, and just who is feeding the words and who must eat them. Do you take this body? Do you take this head?

The joining of two things is predicated on their being separate from each other in the first place. This was not a script which I had written, the original severance of head from body, yet I knew it to be so. Subtle severances seemed to happen every day in a person's life, until finally at the age of seven or eight the desire is already in place - to be united or reunited with a part which has been lost, or is thought to be missing.

I lowered my head and let her rest in the crook of my arm, gathering the blanket around us as though we were standing on the bridge watching the last of the fireworks. The head on the wall was still chattering, like a giddy ventriloquist, without moving her mouth. Her words bounced off every corner of the room and whistled through the pursed lips of the mangle, they settled on the bottles of the spice-rack and rolled between the cracks in the linoleum floor. Is there any body present who objects to this union? Who will give away the bride? Are you with the party of the bride or the party of the groom? Do you take this body? Do you take this head?

At last it seemed the only way to shut her up was to accept her terms, and so I said I do. I looked up into the soft and eager eyes which did not blink, did not weep as the eyes of mothers are said to do at weddings, and spoke the words again I do. I do take this head. I do.

I now pronounce you head and body, said the head on the wall. Let no one tear asunder what herein has been conjoined.

Then was I permitted to kiss my better half on her small pink lips, which were cool and hard like buttons. 